\title{
Short communication: Serum osteoprotegerin concentrations in periparturient dairy cows
}

\author{
Kaoru Hatate, ${ }^{\star} \dagger$ Chiho Kawashima,‡ Masaaki Hanada,§ Mitsunori Kayano,\# and Norio Yamagishi ${ }^{*}{ }^{1}$ \\ *United Graduate School of Veterinary Sciences, Gifu University, 1-1 Yanagido, Gifu 501-1193, Japan \\ †Department of Veterinary Medicine, \\ †Field Center of Animal Science and Agriculture, \\ $\S$ Department of Life Science and Agriculture, and \\ \#Department of Veterinary Medicine Research Center for Global Agromedicine, Obihiro University of Agriculture and Veterinary Medicine, 2-11, \\ Inada-cho, Obihiro, Hokkaido, 080-8555, Japan
}

\begin{abstract}
Dairy cows experience hypocalcemia at the onset of lactation; however, the contribution of bone metabolism to circulating $\mathrm{Ca}$ concentrations during the periparturient period is not well understood. Osteoprotegerin $(\mathrm{OPG})$ protects against loss of skeletal mass by regulating osteoclastogenesis. We previously reported that the bone resorption increased around parturition in dairy cows from the perspective of bone markers in blood. The aim of this study was to explore osteoclastic bone resorption in periparturient dairy cows by measuring changes in serum OPG concentrations around calving. The OPG concentrations were evaluated in primiparous $(\mathrm{n}=9)$ and multiparous $(\mathrm{n}=9)$ cows at $21 \mathrm{~d}$ precalving and over $5 \mathrm{~d}$ after calving. Based on mixed model analyses, the multiparous cows had a higher serum OPG concentration than primiparous cows at precalving and exhibited a significant decline in serum OPG and $\mathrm{Ca}$ concentrations after calving. In contrast to multiparous cows, primiparous cows did not exhibit these changes. Therefore, we hypothesized that multiparous cows preserve their bone mineral content during late pregnancy and activate the osteoclastic bone resorption after calving. Based on our serum OPG data, we identified the different periparturient osteoclastic bone resorption patterns in healthy primiparous and multiparous dairy cows.
\end{abstract}

Key words: dairy cow, osteoprotegerin, parturition

\section{Short Communication}

Calcium mobilization from bone is termed osteoclastogenesis, differentiation into multinucleated osteoclasts

Received December 12, 2017.

Accepted March 21, 2018.

${ }^{1}$ Corresponding author: yamagishi@obihiro.ac.jp that degrade bone. Osteoclastogenesis is regulated by the receptor activator of nuclear factor- $\kappa \mathrm{B}$ ligand (RANKL), a member of the tumor necrosis factor superfamily, and its receptor (Hofbauer et al., 2000). Binding of RANKL to the receptor on precursor osteoclasts initiates gene transcription of osteoclastogenesis (Hofbauer et al., 2000). Osteoprotegerin (OPG), a regulator of bone resorption, inhibits osteoclastogenesis by acting as a decoy receptor for RANKL (Simonet et al., 1997). In general, dairy cows are susceptible to hypocalcemia at the onset of lactation. Because of the slower hormonal response, older cows have a higher risk of clinical hypocalcemia around the time of parturition (parturient paresis, also termed milk fever; Reinhardt et al., 1988). However, the contribution made by bone metabolism to $\mathrm{Ca}$ homeostasis remains incompletely understood in cattle. The activity of tartrate-resistant acid phosphatase 5b (TRAP5b), a bone resorption marker exocytosed by osteoclasts, correlates well with the number of osteoclasts (Halleen, 2006). We previously found that the activity of TRAP5b in the blood of dairy cows began to increase $1 \mathrm{wk}$ before parturition, suggesting that osteoclast numbers had risen before the fall in Ca concentration (Devkota et al., 2015). However, to the best of our knowledge, circulating OPG concentrations in dairy cows have not been studied. The aim of our study was to explore osteoclastic bone resorption in primiparous and multiparous cows by measuring sequential changes in peripartum serum OPG concentrations.

Blood samples were collected from 9 primiparous and 9 multiparous Holstein Friesian cows in the farm of Obihiro University of Agriculture and Veterinary Medicine. They were fed a TMR with ad libitum hay (Table 1). All cows underwent normal calving and were declared clinically healthy $5 \mathrm{~d}$ after parturition. The average number of lactations was 2.7 in multiparous cows (range $=2$ to 4 ). Body condition scores of cows were 3.00 to 3.50 and $\mathrm{BW}$ during the close-up period 
Table 1. Ingredient and nutritional composition of the prepartum and postpartum rations during the study involving 9 primiparous and 9 multiparous dairy cows

\begin{tabular}{lcc}
\hline Item & $\begin{array}{c}\text { Prepartum }^{1} \\
\text { ration }^{1}\end{array}$ & $\begin{array}{c}\text { Postpartum }^{2} \\
\text { ration }^{2}\end{array}$ \\
\hline Ingredient (\% DM, unless noted) & 33.6 & 32.3 \\
Grass silage & 29.1 & 15.5 \\
Corn silage & 12.0 & 0.0 \\
Orchard hay & 6.4 & 0.0 \\
Soybean meal & 0.0 & 3.8 \\
Beet pulp & 0.0 & 5.4 \\
Ground corn & $18.7^{3}$ & $42.8^{4}$ \\
Concentrate mix & 0.1 & 0.1 \\
Vitamin and mineral premix ${ }^{5}$ & 0.1 & 0.1 \\
Magnesium oxide & 0.1 & 0.04 \\
Vitamin E & 41.6 & 42.5 \\
DM (\%) & & \\
Nutrition composition & 15.6 & 15.4 \\
CP (\% DM) & 23.5 & 20.9 \\
ADF (\% DM) & 0.4 & 0.5 \\
Ca (\% DM) & 0.4 & 0.4 \\
P (\% DM) & 1.9 & 1.6 \\
K (\% DM) & 0.2 & 0.3 \\
Mg (\% DM) & 0.2 & 0.3 \\
S (\% DM) & 0.01 & 0.1 \\
Na (\% DM) & 0.4 & 0.4 \\
Cl (\% DM) & 23.4 & 15.3 \\
DCAD (mEq/100 g of DM) & & \\
\hline
\end{tabular}

${ }^{1}$ Prepartum ration (from -28 to $-1 \mathrm{~d}$ prepartum).

${ }^{2}$ Postpartum ration (after calving to mid-lactation).

${ }^{3}$ Dry Base 17 (nutrient composition on a DM basis: $17.0 \%$ CP, $2.0 \%$ crude fat, $10 \%$ crude fiber, $0.05 \% \mathrm{Ca}$ and $0.5 \% \mathrm{P} ; 71 \% \mathrm{TDN}$, including corn, lupin, wheat, bran, rapeseed cake, and so on; Hokuren Cooperative Feed Mills Co. Ltd., Hokkaido, Japan).

${ }^{4}$ Milk Trend 74 (nutrient composition on a DM basis: $18 \%$ CP, $2.5 \%$ crude fat, $11 \%$ crude fiber, $0.55 \% \mathrm{Ca}$ and $0.4 \% \mathrm{P} ; 74.0 \% \mathrm{TDN}$, including corn, corn gluten feed, bran, corn distillers by-products, and rapeseed cake; Chubu Shiryo Co. Ltd., Nagoya, Japan).

${ }^{5}$ Yokabita M [contents per gram: 5,000 IU of vitamin A, 1,000 IU of vitamin $\mathrm{D}_{3}, 2 \mathrm{mg}$ of vitamin $\mathrm{E}, 0.2 \mathrm{mg}$ of vitamin $\mathrm{K}_{3}, 0.5 \mathrm{mg}$ of vitamin $\mathrm{B}_{1}, 1 \mathrm{mg}$ of vitamin $\mathrm{B}_{2}, 0.1 \mathrm{mg}$ of vitamin $\mathrm{B}_{6}, 1 \mu \mathrm{g}$ of vitamin $\mathrm{B}_{12}, 6 \mathrm{mg}$ of nicotinic acid, $2 \mathrm{mg}$ of chlorine chloride, $10 \mathrm{mg}$ of pantothenic acid, $156 \mu \mathrm{g}$ of $\mathrm{Mn}\left(\mathrm{MnSO}_{4}\right), 700$ of $\mu \mathrm{g} \mathrm{Zn}\left(\mathrm{ZnSO}_{4}\right), 550 \mu \mathrm{g}$ of $\mathrm{Fe}\left(\mathrm{FeSO}_{4}\right)$, $139 \mu \mathrm{g}$ of $\mathrm{Cu}\left(\mathrm{CuSO}_{4}\right), 325 \mu \mathrm{g}$ of $\mathrm{I}\left(\mathrm{Ca}\left(\mathrm{IO}_{3}\right)_{2}\right), 38 \mu \mathrm{g}$ of $\mathrm{Co}\left(\mathrm{CoSO}_{4}\right), 1$ $\mathrm{mg}$ of methionine, $0.5 \mathrm{mg}$ of lysine hydrochloride and $50 \mathrm{ng}$ of ethoxyquin; Snow Brand Seed Co. Ltd., Sapporo, Japan].

${ }^{6} \mathrm{~A}$ lack of $\mathrm{Na}$ intake was compensated by mineral salt brick.

was $594 \pm 86.9$ and $729 \pm 49.5 \mathrm{~kg}($ mean $\pm \mathrm{SD})$ in the primiparous and multiparous groups, respectively. The average milk production of the primiparous and the multiparous cows during the 5 -d postcalving period was 19.8 and $28.1 \mathrm{~kg} / \mathrm{d}$, respectively. Dry matter intake of the primiparous and the multiparous cows, predicted by the NRC (2001) equations, were 10.1 and $14.2 \mathrm{~kg} / \mathrm{d}$ for the close-up period and 10.8 and $13.6 \mathrm{~kg} / \mathrm{d}$ for the 5-d postpartum period, respectively.

Coccygeal blood samples were withdrawn $3 \mathrm{wk}$ before calving $(-21 \mathrm{~d})$ and 4 times after calving [immediately after calving $(0 \mathrm{~d}), 12 \mathrm{~h}(0.5 \mathrm{~d})$, and 2 and $5 \mathrm{~d}$ later]. The experimental design was approved by the Obihiro University of Agriculture and Veterinary Medicine Laboratory Animal Care and Use Committee (approval \#28-156).

Serum Ca concentrations were measured by a biochemical autoanalyzer (TBA-120FR, Toshiba Medical Systems, Otawara, Japan). Serum OPG concentrations were measured using a commercial kit (Bovine OPG ELISA kit, NeoScientific, Cambridge, MA) according to the manufacturer's instructions (https://neobiolab .com/elisa-kits/bovine-opg/bo0027). This ELISA is a quantitative competitive immunoassay that uses an antibody against bovine OPG. After incubation with horseradish peroxidase at $37^{\circ} \mathrm{C}$ for $60 \mathrm{~min}$, OPG concentrations were measured by recording absorbances at $450 \mathrm{~nm}$. The TRAP5b concentrations in plasma were measured by a fluorometric method using naphtholASBI-phosphate (Wako Pure Chemical Corp., Osaka, Japan) as the substrate. We used a modified version of the Janckila method (Yamagishi et al., 2009; Matsuo et al., 2014), where 10- $\mu \mathrm{L}$ amounts of plasma were added to a $0.25-\mathrm{mmol} / \mathrm{L}$ naphthol-ASBI-phosphate solution containing $100 \mathrm{mmol} / \mathrm{L}$ of sodium acetate and $50 \mathrm{mmol} / \mathrm{L}$ of sodium tartrate (Wako Pure Chemical Corp.). Following incubation at $37^{\circ} \mathrm{C}$ for $30 \mathrm{~min}$, fluorescence was detected (excitation wavelength = $405 \mathrm{~nm}$, emission wavelength $=535 \mathrm{~nm}$ ) using a multilabel counter (ALVO MX/ Light 1420; PerkinElmer, Waltham, MA). The intra- and interassay coefficients of variation were 11.3 and $9.7 \%$ for the OPG ELISA and 5.6 and $7.8 \%$ for TRAP5b fluorometry, respectively.

All data were analyzed in the mixed model for repeated measures using SAS enterprise guide (ver. 7.1, SAS Institute Inc., Cary, NC). The fixed effects (group, day, and group $\times$ day) with the random effect of individual cows were assessed, followed by Tukey's posthoc test. The Spearman's rank correlation analysis was done by for nonparametric distributions. All numerical values are shown as mean \pm standard error of the mean and the level of significance was set at $P<0.05$.

Figure 1 shows the changes in serum Ca concentrations around the time of parturition in primiparous and multiparous dairy cows. We observed no apparent differences in serum Ca concentrations between groups. The multiparous group decreased the serum Ca concentrations significantly $(P<0.01)$ from $-21 \mathrm{~d}$ to $0 \mathrm{~d}$ $(2.5 \pm 0.04$ to $2.1 \pm 0.08 \mathrm{mmol} / \mathrm{L})$, and returned to the prepartum concentrations at $5 \mathrm{~d}(2.4 \pm 0.04 \mathrm{mmol} / \mathrm{L})$.

Figure 2 shows the changes in serum OPG concentrations and plasma TRAP5b activities around the time of parturition in primiparous and multiparous dairy cows. The serum OPG concentrations were significantly higher $(P<0.01)$ in the multiparous compared with the primiparous group at $-21 \mathrm{~d}(7.5 \pm 0.4$ vs. $5.0 \pm$ 
Table 2. Spearman's rank correlation coefficient $(\rho)$ and $P$-values between the serum osteoprotegerin $(\mathrm{OPG})$ and $\mathrm{Ca}$ concentrations in 18 dairy Holstein parturient cows

\begin{tabular}{lccccc}
\hline Item & $-21 \mathrm{~d}$ & $0 \mathrm{~d}$ & $0.5 \mathrm{~d}$ & $2 \mathrm{~d}$ & $5 \mathrm{~d}$ \\
\hline$\rho$ & 0.06 & 0.45 & 0.04 & 0.29 & 0.14 \\
$P$-value & 0.81 & 0.06 & 0.87 & 0.25 & 0.57 \\
\hline
\end{tabular}

$0.6 \mathrm{ng} / \mathrm{mL})$. Compared with $-21 \mathrm{~d}$, the OPG concentration fell significantly $(P<0.01)$ at $0 \mathrm{~d}(3.9 \pm 0.3$ $\mathrm{ng} / \mathrm{mL})$ and remained low until $5 \mathrm{~d}(3.7-4.4 \mathrm{ng} / \mathrm{mL})$ in the multiparous group, but not in the primiparous group (mean $=5.0-5.6 \mathrm{ng} / \mathrm{mL}$ ). The plasma TRAP5b activities peaked at $0 \mathrm{~d}$ in both the multiparous and the primiparous groups $(2.1 \pm 0.2$ and $3.1 \pm 0.3 \mathrm{U} / \mathrm{L})$. The TRAP5b concentrations in the primiparous group during the experimental period were significantly $(P<$ 0.01) higher than those in the multiparous group. We found no significant correlations between serum OPG and Ca concentrations at each time point (Table 2).

In the multiparous cows, the serum OPG concentration was higher than that of primiparous cows at -21 $\mathrm{d}$ and decreased after calving. In primiparous cows, the serum OPG concentration was stable during the peripartum period; OPG prevents bone resorption and protects ovariectomized rats against excessive skeletal loss (Simonet et al., 1997). Multiparous cows

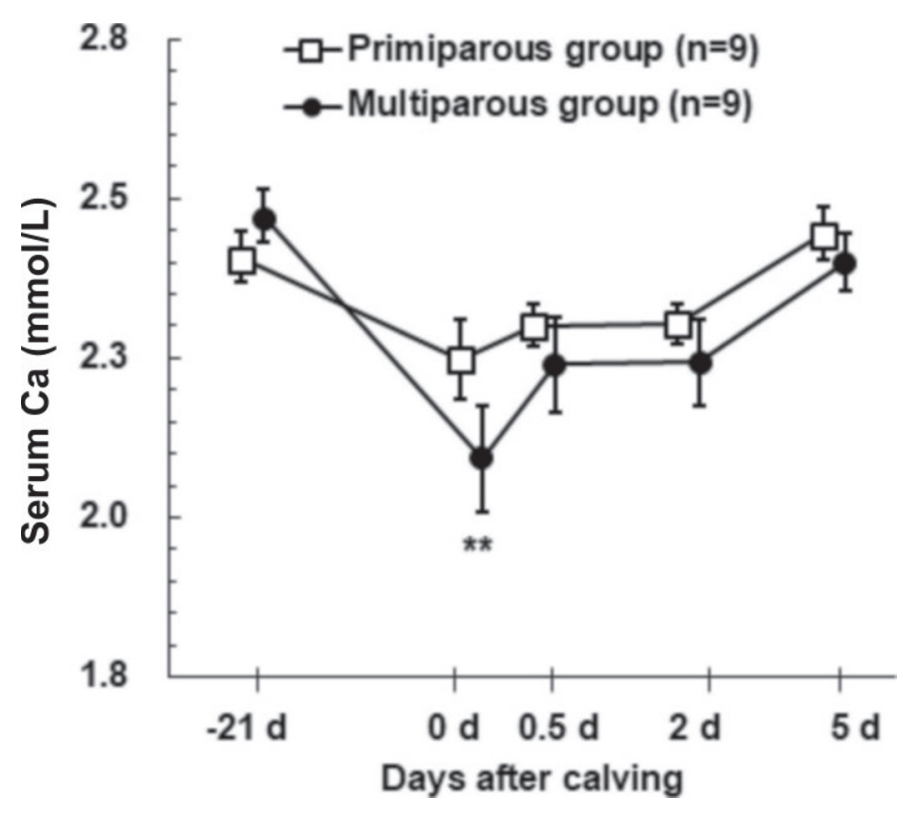

Figure 1. Changes in serum Ca concentrations around the time of parturition in the primiparous $(\square ; \mathrm{n}=9)$ and multiparous $(\mathbf{n}=9)$ groups ( -21 to $5 \mathrm{~d}$ relative to calving; means \pm SEM). ${ }^{* *}$ Significant decreases from the concentrations at $-21 \mathrm{~d}$ in the multiparous group $(P<0.01)$. use the dry period to replenish the bone mineral content lost during the last lactation (Reinhardt et al., 1988). Primiparous cows are often still growing and, as such, bone growth and bone remodeling is more active
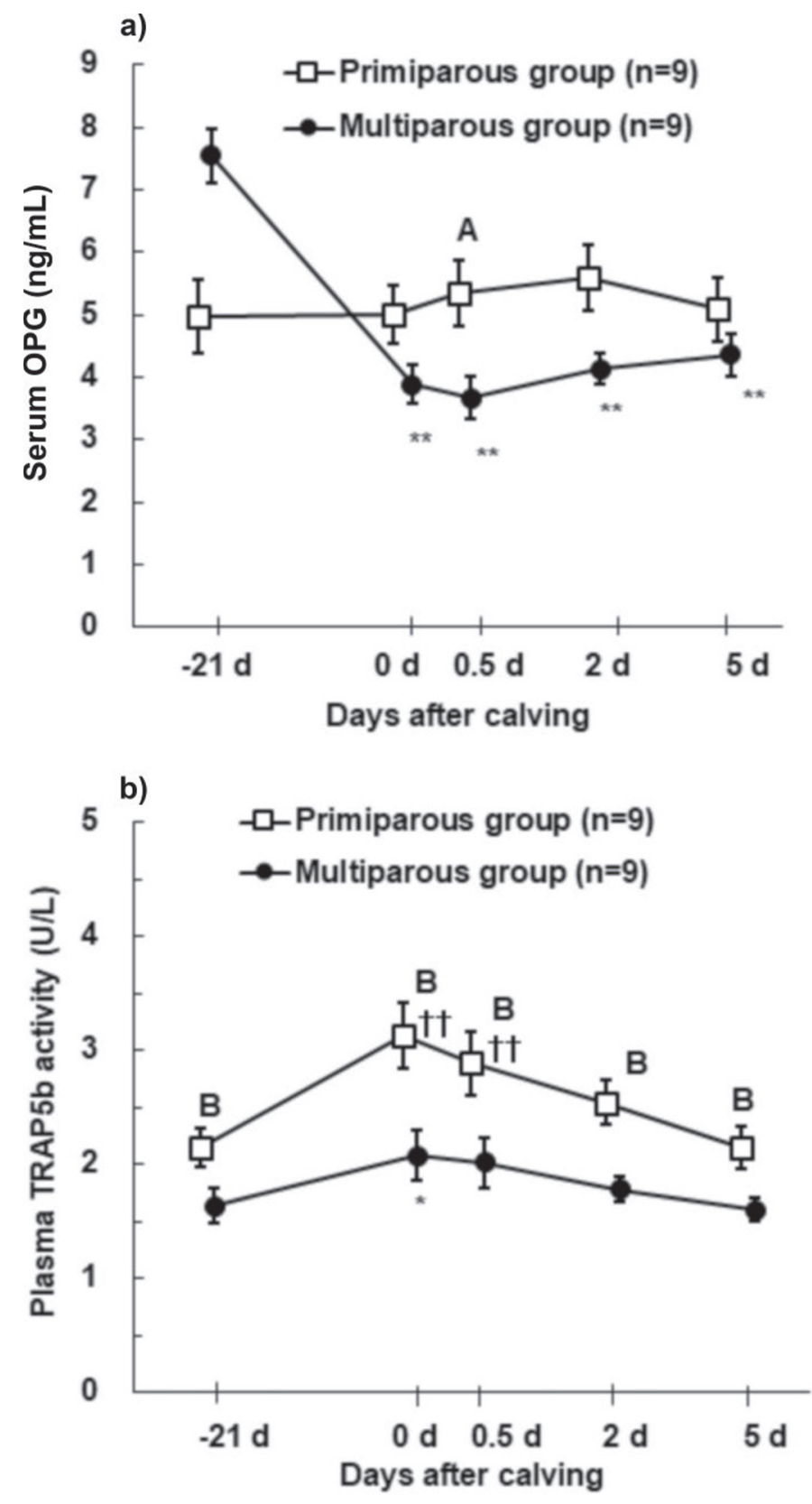

Figure 2. Changes in serum osteoprotegerin (OPG) concentrations and plasma tartrate-resistant acid phosphatase 5b (TRAP5b) activities around the time of parturition in the primiparous $(\square ; n=9)$ and multiparous $(\bullet ; n=9)$ groups ( -21 to 5 d relative to calving; means \pm SEM). Different letters (A,B) indicate significant differences between groups (B: $P<0.01$, A: $P<0.05)$. Asterisks denote a significant difference from the value at $-21 \mathrm{~d}$ in the multiparous group $\left({ }^{*} P<0.01\right.$, $* P<0.05)$; daggers indicate a significant difference from the value at $-21 \mathrm{~d}$ in the primiparous group $(\dagger \dagger P<0.01)$. 
through gestation than would be expected in mature nongrowing multiparous cows, in which OPG protects their bone from excessive loss during late pregnancy (Wathes et al., 2007; Yamagishi et al., 2009).

Most postpartum dairy cows experience varying degrees of hypocalcemia as lactational $\mathrm{Ca}$ demand increased (Reinhardt et al., 1988). We found that multiparous cows exhibited an acute decline in the serum Ca concentration at calving, with lower serum OPG concentrations compared with the prepartum values. However, primiparous cows did not exhibit any marked difference in either serum $\mathrm{Ca}$ or OPG concentrations from prepartum values. These data suggest that bone resorption only increased immediately postpartum based on TRAP5b data in multiparous cows compared with 3 wk prepartum. This contrasted primiparous cows, whose OPG concentrations remained constant over the sampling period but showed a higher and more sustained evidence of increased bone resorption postpartum based on TRAP5b. Our correlation analysis suggests this OPG-induced Ca mobilization was not the simultaneous response to Ca insufficiency. However, due to the lack of the sequential changes in the serum OPG concentrations toward calving, it is still unknown how the circulating OPG regulates the sudden Ca loss in calving cows.

At the day of calving, dairy cows exhibited elevated levels of TRAP5b but only multiparous cows reduced serum Ca levels, implying the osteoclasts increased irrespective of those resorbing capacity, as TRAP $5 \mathrm{~b}$ is secreted by osteoclasts at various stages of maturity (Halleen, 2006). In osteoporotic rats, TRAP5b in the osteocytes and osteoblasts act together with RANKL/ OPG when regulating osteoclastogenesis (Solberg et al., 2015). Moreover, TRAP5b gene expression was elevated during osteocytic bone remodeling in lactating mice (Qing et al., 2012). Therefore, plasma TRAP5b activity may be influenced by complicated bone-resorbing interactions among osteoblasts, osteoclasts, and osteocytes. Further studies are needed to understand the precise mechanism underlying osteocytic osteolysis and the biochemical significance of blood TRAP5b activity in bone resorption.

Some studies reported the changes of other bone resorption markers in multiparous cows during the transition period. Liesegang et al. (2007) observed the serum carboxyterminal telopeptide of type-I collagen (ICTP) concentration restrained before calving and increased during early postpartum period. Taylor et al. (2009) reported a similar result using serum deoxypyridinoline (DPD), as the inhibition of bone resorption had continued around parturition. Devkota et al. (2015) revealed the increase in the number of bone-resorbing cells before parturition; on the other hand, Teramura et al. (2015) found the acute decline of the serum crosslinked N-telopeptide of type I collagen (NTx) on the day of calving.

In conclusion, we found that the serum OPG concentration in multiparous cows was high at 3 wk prepartum, but lowered after calving to the same level as that in primiparous cows, suggesting the different pattern of peripartum bone metabolism between primiparous and multiparous cows. In contrast to primiparous cows, multiparous cows seemed to activate their osteoclastic bone degradation at calving. Based on our pilot study with the small sample size, we suggest that the further studies are needed to clarify how the changes in circulating OPG concentrations associated with its Ca levels in periparturient dairy cows with various health status.

\section{ACKNOWLEDGMENTS}

We appreciate Acosta Ayala Thomas Javier, Akihiro Fujieda, Aung Htun, and Rishalaitihan Maimaiti (Obihiro University of Agriculture and Veterinary Medicine, Obihiro, Japan) for their support in monitoring the calvings. We also gratefully thank Katsuya Kida and all staff of the Field Center of Animal Science and Agriculture, Obihiro University of Agriculture and Veterinary Medicine, for providing the data about feeding and supplements in the farm.

\section{REFERENCES}

Devkota, B., M. Takahashi, S. Sato, K. Sasaki, A. Ueki, T. Osawa, M. Takahashi, and N. Yamagishi. 2015. Plasma fluctuation in estradiol-17 $\beta$ and bone resorption markers around parturition in dairy cows. J. Vet. Med. Sci. 77:875-878.

Halleen, J. M. 2006. Tartrate-resistant acid phosphatase 5b (TRACP5b) as a maker of bone resorption. Clin. Lab. 52:499-509.

Hofbauer, L. C., S. Khosla, C. R. Dunstan, D. L. Lacey, W. J. Boyle, and L. Riggs. 2000. The roles of osteoprotegerin and osteoprotegerin ligand in the paracrine regulation of bone resorption. J. Bone Miner. Res. 15:2-12.

Liesegang, A., C. Chiappi, J. Risteli, J. Kessler, and H. D. Hess. 2007. Influence of different calcium contents in diets supplemented with anionic salts on bone metabolism in periparturient dairy cows. J. Anim. Physiol. Anim. Nutr. (Berl.) 91:120-129.

Matsuo, A., A. Togashi, K. Sasaki, B. Devkota, T. Hirata, and N. And Yamagishi. 2014. Diurnal variation of plasma bone markers in Japanese Black calves. J. Vet. Med. Sci. 76:1029-1032.

NRC. 2001. Nutrient Requirements of Dairy Cattle. 7th rev. ed. Natl. Acad. Sci., Washington, DC.

Qing, H., L. Ardeshirpour, P. D. Pajevic, V. Dusevich, K. Jähn, S. Kato, J. Wysolmerski, and L. F. Bonewald. 2012. Demonstration of osteocytic perilacunar/canalicular remodelling in mice during lactation. J. Bone Miner. Res. 27:1018-1029.

Reinhardt, T. A., R. L. Horst, and J. P. Goff. 1988. Calcium, phosphorus, and magnesium homeostasis in ruminants. Vet. Clin. North Am. Food. Anim. Pract. 4:331-350.

Simonet, W. S., D. L. Lacey, C. R. Dunstan, M. Kelley, M. -S. Chang, R. Luthy, H. Q. Nguyen, S. Wooden, L. Bennett, T. Boone, G. Shimamoto, M. DeRose, R. Elliott, A. Colombero, H. -L. Tan, G. 
Trail, J. Sullivan, E. Davy, N. Bucay, L. Renshaw-Gegg, T. M. Hughes, D. Hill, W. Pattison, P. Campbell, S. Sander, G. Van, J. Tarpley, P. Derby, R. Lee, and W. J. Boyle. 1997. Osteoprotegerin: A novel secreted protein involved in the regulation of bone density. Cell 89:309-319.

Solberg, L. B., E. Stang, S.-H. Brorson, G. Anderson, and F. P. Reinholt. 2015. Tartrate-resistant acid phosphatase (TRAP) co-localizes with receptor activator of NF-KB ligand (RANKL) and osteoprotegerin (OPG) in lysosomal-associated membrane protein 1 (LAMP1)-positive vesicles in rat osteoblasts and osteocytes. Histochem. Cell Biol. 143:195-207.

Taylor, M. S., K. F. Knowlton, M. L. McGillard, W. S. Swecker, J. D. Ferguson, Z. Wu, and M. D. Hanigan. 2009. Dietary calcium has little effect on mineral balance and bone mineral metabolism through twenty weeks of lactation in Holstein cows. J. Dairy Sci. $92: 223-237$.
Teramura, M., S. Wynn, M. Reshalaitihan, W. Kyuno, T. Sato, M. Ohtani, C. Kawashima, and M. Hanada. 2015. Supplementation with difructose anhydride III promotes passive calcium absorption in the small intestine immediately after calving in dairy cows. J. Dairy Sci. 98:8688-8697.

Wathes, D. C., Z. Cheng, N. Bourne, V. J. Taylor, M. P. Coffey, and S. Brotherstone. 2007. Differences between primiparous and multiparous dairy cows in the inter-relationships between metabolic traits, milk yield and body condition score in the periparturient period. Domest. Anim. Endocrinol. 33:203-225.

Yamagishi, N., K. Takehana, D. Kim, M. Miura, T. Hirata, B. Devkota, S. Sato, and K. Furuhama. 2009. Fluorometric method for measuring plasma tartrate-resistant acid phosphatase isoform 5b and its application in cattle. J. Vet. Med. Sci. 71:1637-1642. 